\title{
The use of heat transformers for the low-temperature secondary energy resources recovery in non-ferrous metallurgy enterprises
}

\author{
A Sh Alimgazin ${ }^{2}, S$ A Prishchepova ${ }^{1}, I A$ Sultanguzin $^{1, *}, A V$ Fedyukhin $^{1}, Y u V$ Yavorovsky $^{1}$, and $A I$ Bartenev $^{1}$ \\ ${ }^{1}$ National Research University “Moscow Power Engineering Institute” (NRU “MPEI”), 17 Krasnokazarmennaya Street, Moscow, \\ 111250 \\ ${ }^{2}$ L.N. Gumilyov Eurasian National University, Satpaev st., 2, 010008, Nur-Sultan, Republic Kazakhstan
}

\begin{abstract}
The paper discusses the concept of developing schemes for the utilization of low potential secondary energy resources waste heat in heat transformers (HT). There ara several examples of using HT in non-ferrous metallurgy plants in Russia and Kazakhstan: the production of nickel, zinc and ferroalloys. In the case of nickel production, two schemes are proposed for consideration: for summer and winter modes. The main object of study is a nickel production scheme using a lithium bromide absorption chiller ( $\mathrm{AbCh}$ ) in the summer. The nickel production process needs cold. In the proposed scheme, the main source of utilized low-grade waste heat for $\mathrm{AbCh}$ is recycled water. The basic parameters were calculated under various extreme conditions, the energy effect of the circuit modernization was estimated, and equipment was selected. Another example of the HT use is the use of a heat pump unit (HPU) in the production of zinc and ferroalloys. HPU is designed to heat feed water before chemical water treatment and at the same time to "cool down" the circulating water, which is then used for electrolysis, replacing purchased artesian water.
\end{abstract}

\section{Introduction}

Due to a decrease in the quantity of fossil fuels, its rise in price on the world market and aggravation of environmental problems, energy efficiency increasing through the use of secondary energy resources (SER) has become more relevant and is gaining world significance The scarce of SER use leads to thermal pollution of the environment [1]. Non-ferrous metallurgy should be given special attention, since there is a large amount of excess heat in it in the form of industrial effluents or reverse cycles. This excess heat can be used in HT to generate cold or heat with a higher potential $[2,3]$. This heat transforms into the heat of hot water, suitable for the needs of hot water supply (HWS), heating or ventilation of an enterprise [4-8]. The conversion of waste heat into cold became possible with the advent of absorption chillers. The resulting cold can be used both in the technological processes of the enterprise, and for the needs of air conditioning in buildings.

The article discusses the modernized nickel production technology in Russia, which requires constant maintenance of the circulating water temperature level at the inlet to the production of not more than $20^{\circ} \mathrm{C}$ in winter and summer. It also provides an example of the successful introduction of HPU in zinc production and discusses the prospects for their application at a ferroalloy plant in the Republic of Kazakhstan.

\section{$2 \mathrm{HT}$ use in the nickel production unit}

Below is a calculation of tubular furnaces reaction excess heat utilization of a nickel production unit (NPU). In accordance with the technology, cooling of $400 \mathrm{~m} 3 / \mathrm{h}$ from 85 to $20^{\circ} \mathrm{C}$ is required.

The most responsible is not only the use of SER, but also the provision of a stable technological process with cooling of the coolant to predetermined temperatures, both in winter and summer periods.

It is proposed to consider two ways of heat utilization (Figure 1):

- in the winter period, it is necessary to use heat pumps to heat the return water of the nickel production workshop heat network and cold feed water of the thermal power plant boiler. In winter the reverse water circuit cooling of the NPU in the heat exchangers 9 and 11 is quite sufficient and additional cold from the $\mathrm{AbCh}$ is not required.

- in summer period after NPU reaction heat recovers for heating the return water of the heating network and cold feed water of the thermal power plant boiler it is cooled to $20^{\circ} \mathrm{C}$ in $\mathrm{AbCh}$ [9]. 


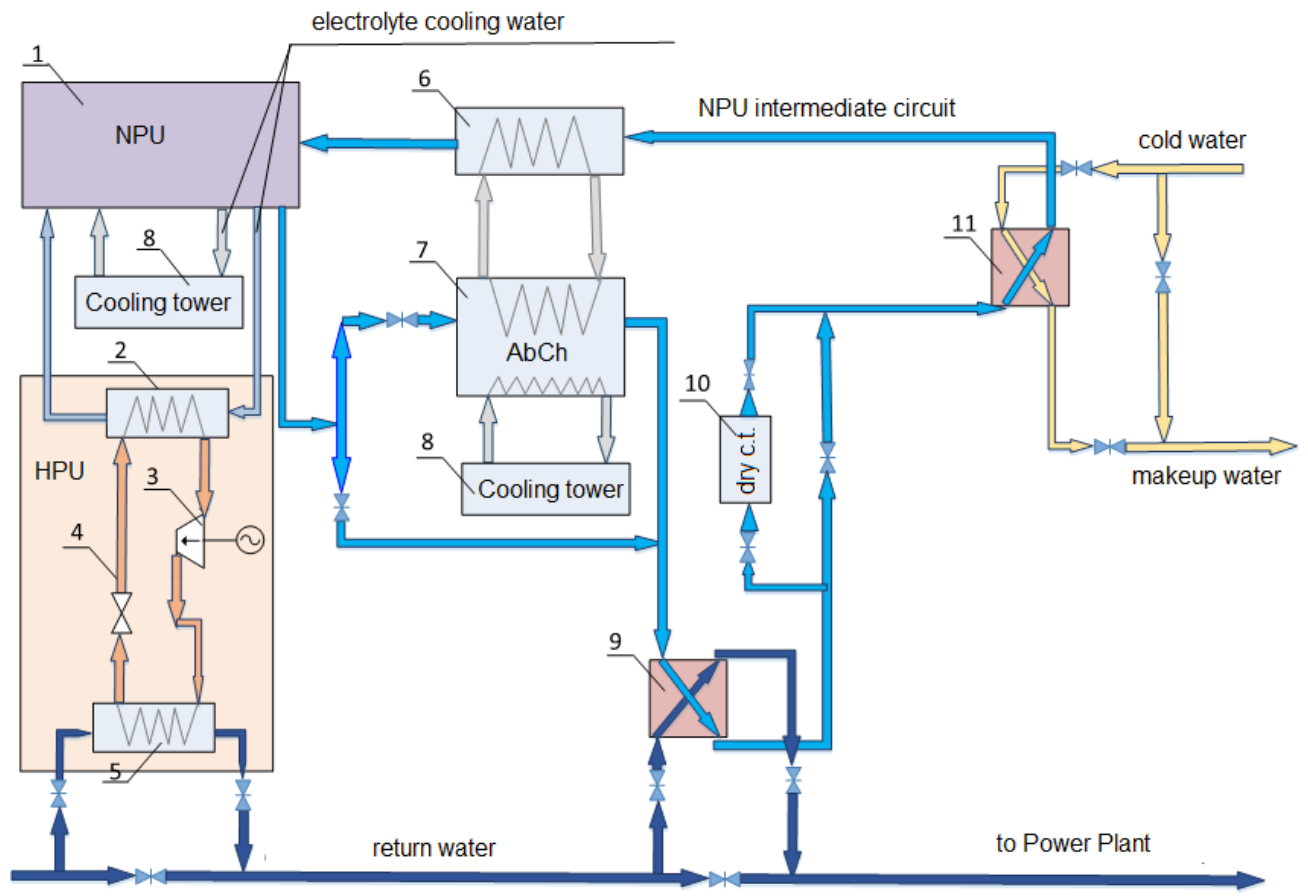

Fig. 1. The general scheme of heat recovery. 1 -nickel production unit (NPU); 2 - heat pump evaporator; 3 - heat pump compressor; 4 - throttle; 5 - heat pump capacitor; 6 - water-water heat exchanger of $\mathrm{AbCh} ; 7$ - AbCh; 8 - cooling towers; 9 water-to-water heat exchanger for return water heating; 10 - a complex of dry cooling towers; 11 - water-to-water heat exchanger for thermal power station make-up water heating.

Figure 1 shows the general scheme of heat recovery in winter and summer modes.

\section{NPU SER recovery in winter period}

Figure 2 shows a diagram of low-grade heat utilization using a heat pump to heat the return water of the heating network in the NPU in winter at an outdoor temperature of $-15{ }^{\circ} \mathrm{C}[8,10,11]$.
The use of a heat pump reduces the water temperature from $50{ }^{\circ} \mathrm{C}$ to $40^{\circ} \mathrm{C}$ at a flow rate of $550 \mathrm{t} / \mathrm{h}$ from an electrolyte cooling heat exchanger.

The compressor capacity of the vapor compression HPU is $1017 \mathrm{~kW}$ with a compression ratio of 2.2. The coefficient of performance (COP) is quite high: $\mathrm{COP}=$ $\mathrm{Q}_{\mathrm{T}} / \mathrm{N}_{\mathrm{K}}=7226 \mathrm{~kW} / 1017 \mathrm{~kW}=7.11$



Fig. 2. Scheme of low-grade heat utilization using a heat pump in winter at an outdoor temperature of $-15^{\circ} \mathrm{C}$. 


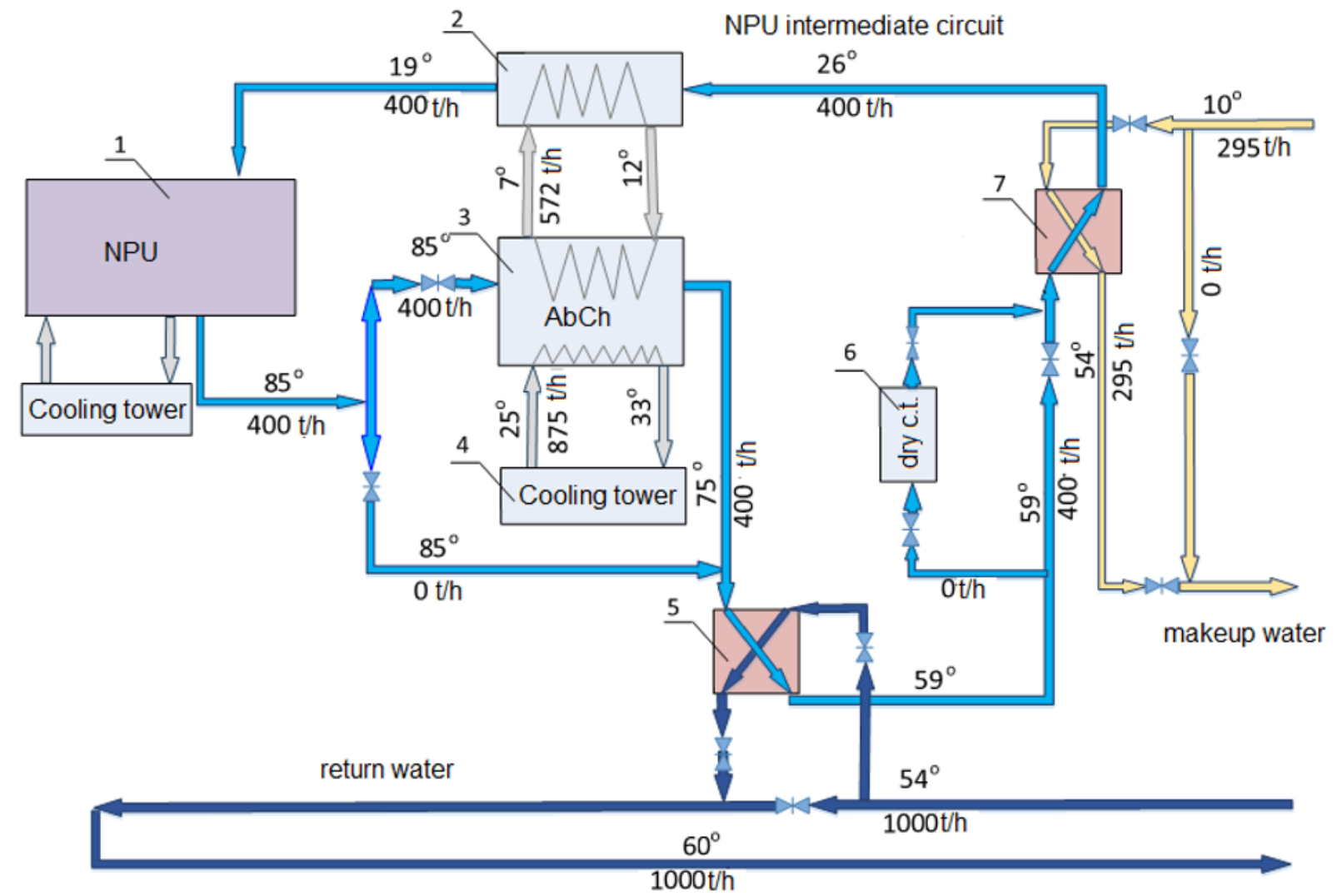

Fig. 3. Schematic diagram of the nickel production installation water circuit with make-up water parameters $\mathrm{Gmw}=295 \mathrm{t} / \mathrm{h}$, $\mathrm{tmw}=10^{\circ} \mathrm{C} .1-$ nickel production installation (NPI); 2 - water-water heat exchanger of $\mathrm{AbCh} ; 3-\mathrm{AbCh} ; 4-$ cooling towers; 5 - water-to-water heat exchanger for return water heating; 6 - a complex of dry cooling towers; 7 - water-to-water heat exchanger for thermal power station make-up water heating.

The heat pump allows to produce thermal energy to heat the water of the NPU heating network in amount Qt $=7226 \mathrm{~kW}$.

The amount of obtained useful heat energy after NPU reactionary heat recovery for heating water of the heating network and feed water of the thermal power plant boiler is $37.2 \mathrm{MW}$.

\section{NPU SER recovery in summer period}

The modernized nickel production technology requires constant maintenance of the circulating water temperature level at the inlet to the production of not more than $20^{\circ} \mathrm{C}$. In accordance with this, as well as for the outlet circulating water heat utilization, it is proposed to use the $\mathrm{AbCh}$.

The following advantages compared to compression refrigeration machines dictate the choice of $\mathrm{AbCh}$ :

- Full automation.

- Long service life (at least 20 years).

- Minimum power consumption. Electricity is required for the operation of pumps and automation.

- The minimum noise level.

- Environmentally friendly. The refrigerant is ordinary water. [12]

- Recovers the thermal energy of the discharged hot water, flue gases or production processes.

- Fire and explosion safety.
The principle of diagram operation is as follows: a stream of water heated during production (1) to a temperature $\mathrm{t}_{1}=84-85^{\circ} \mathrm{C}$ is used as heating water in $\mathrm{AbCh}$ circuit (3), where it is cooled to $\Delta \mathrm{t}_{2}=10-11^{\circ} \mathrm{C}$, then in the return water heat exchanger (5), after which it is additionally cooled in the make-up water heat exchanger (7), leaves it with a temperature $t_{3}=25-27^{\circ} \mathrm{C}$ and is additionally cooled in the heat exchanger (2) to a temperature $t_{4}=19.5-20{ }^{\circ} \mathrm{C}$, after which it returns to NPU. (Figure 3)

To ensure the required temperature level of the NPU circulating water under extreme conditions, a complex of dry cooling towers is provided (6). In these cases, part of the circulating water stream is taken from the main collector and cooled in dry cooling towers, after which it is mixed with the main stream.

As part of the development and modeling of circuit solutions, calculations were carried out at three critical points with different indicators of temperatures $(t)$ and flow rates $(\mathrm{G})$ of power plant makeup cold water, only one will be considered in the work:

$-\mathrm{G}=250 \mathrm{t} / \mathrm{h}, \mathrm{t}=10^{\circ} \mathrm{C}$

$-\mathrm{G}=295 \mathrm{t} / \mathrm{h}, \mathrm{t}=10^{\circ} \mathrm{C}$, the flow rate is taken as the hourly average for the warmest day of summer, the water temperature is also taken with a reserve of $\Delta \mathrm{t}=1{ }^{\circ} \mathrm{C}$ (Figure 3);

$$
-\mathrm{G}=295 \mathrm{t} / \mathrm{h}, \mathrm{t}=15^{\circ} \mathrm{C} \text {. }
$$




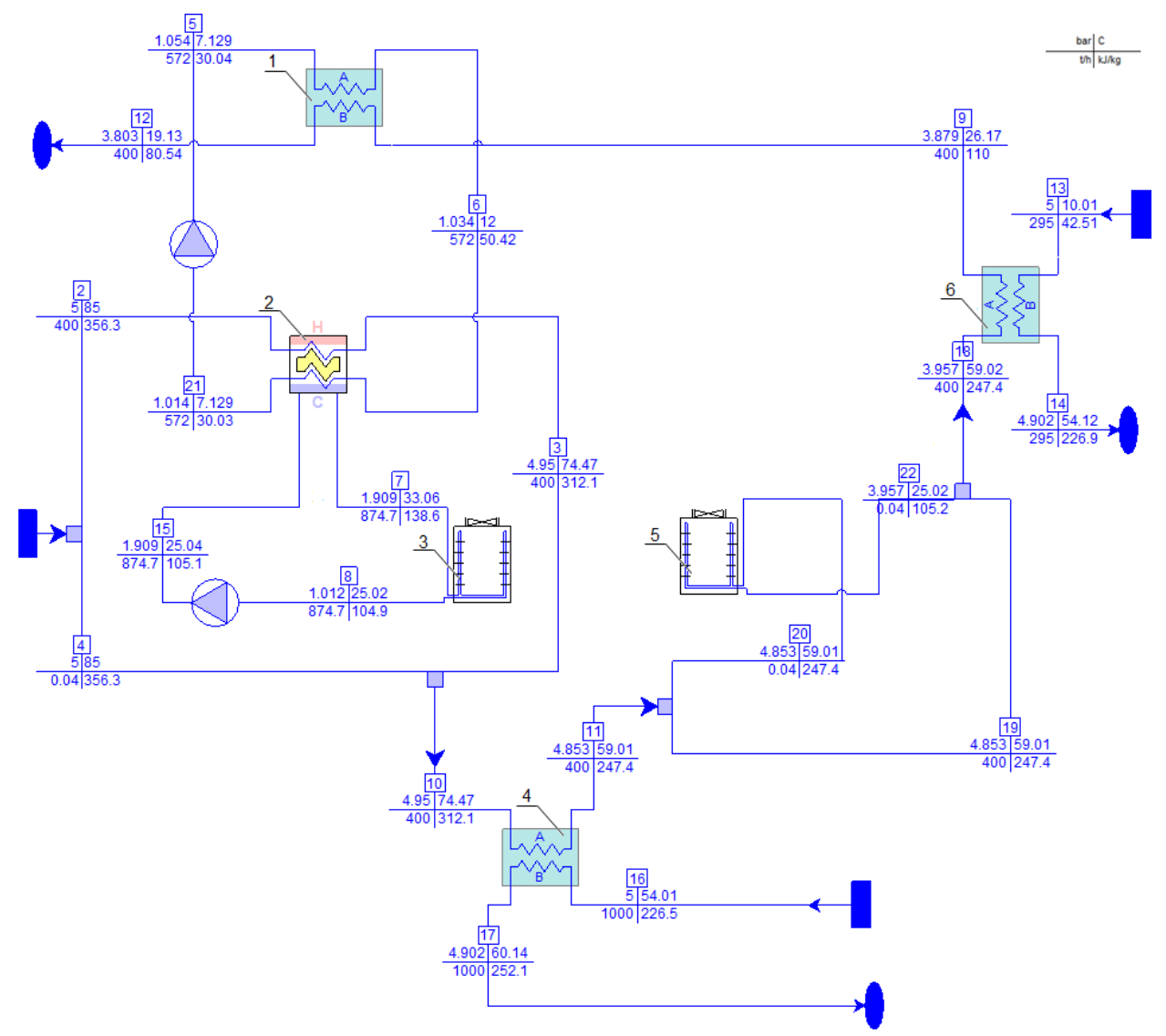

Fig. 4. Calculation of the NPI water circuit diagram with make-up water parameters $\mathrm{Gmw}=295 \mathrm{t} / \mathrm{h}, \mathrm{tmw}=10^{\circ} \mathrm{C}$ in THERMOFLEX. 1 - water-water heat exchanger of AbCh; 2 - AbCh; 3 - cooling towers; 4 -water-to-water heat exchanger for return water heating; 5 - a complex of dry cooling towers; 6 - water-to-water heat exchanger for thermal power station makeup water heating.

Computer simulation of the new nickel production scheme was carried out in the Thermoflex software environment (Figure 4). Thermoflex is a modular program with a graphical interface. The user can create a model of any station using more than one hundred and seventy-five symbolic images contained in its database. It is also possible to simulate almost any type of modern installations and heat sources in conjunction with heating networks $[13,14]$.

Computer simulation has shown the sufficiency of this design for maintaining technological needs and the optimal use of the production water recycling potential.

The main characteristics of the simulated chiller are presented in Table 1.

Table 1. Characteristics of the simulated AbCh.

\begin{tabular}{|c|l|c|}
\hline Num. & \multicolumn{1}{|c|}{ Indicator } & Value \\
\hline $\mathbf{1}$ & Heating water flow, $\mathrm{m} 3 / \mathrm{h}$ & 400 \\
\hline $\mathbf{2}$ & Cooled water flow, $\mathrm{m} 3 / \mathrm{h}$ & 572 \\
\hline $\mathbf{3}$ & Cooling water flow, $\mathrm{m} 3 / \mathrm{h}^{\circ}$ & 874 \\
\hline $\mathbf{4}$ & Cooled water temperature $^{\circ} \mathrm{C}$ & $12 / 7$ \\
\hline $\mathbf{5}$ & Cooling water temperature $^{\circ} \mathrm{C}$ & $25 / 33$ \\
\hline $\mathbf{6}$ & Heating water temperature $^{\circ} \mathrm{C}$ & $85 / 74$ \\
\hline
\end{tabular}

Other indicators of temperatures and flow rates of the circuit solution, see Figure 3.

Waste heat recovery in $\mathrm{AbCh}$ not only reduces primary fuel consumption, but also thermal pollution of the environment. Water of the intermediate circuit for NPU reaction heat utilization with a temperature of 85 ${ }^{\circ} \mathrm{C}$ and a flow rate of up to $400 \mathrm{~m} 3 / \mathrm{h}$ is used as a source of thermal energy for the AbCh.

Heating water is cooled from $85^{\circ} \mathrm{C}$ to $74.5^{\circ} \mathrm{C}$ in $\mathrm{AbCh}$. The heat energy consumption with heating water in $\mathrm{AbCh}$ is $4.9 \mathrm{MW}$. Then it enters the heat exchanger for heating the reverse water of the NPU heat network from $54^{\circ} \mathrm{C}$ to $60^{\circ} \mathrm{C}$ with a flow rate of $1000 \mathrm{~m} 3 / \mathrm{h}$. The heating water is cooled from $74.5^{\circ} \mathrm{C}$ to $59^{\circ} \mathrm{C}$ in the heat exchanger of the NPU heating system water. The heat load of this heat exchanger is $7.2 \mathrm{MW}$.

Then it enters the heat exchanger of power plant boiler feed water, where it is cooled from $59^{\circ} \mathrm{C}$ to $26.17^{\circ} \mathrm{C}$. Makeup water is heated from $10^{\circ} \mathrm{C}$ to $54.1^{\circ} \mathrm{C}$. The heat load of this heat exchanger is $15.3 \mathrm{MW}$.

In $\mathrm{AbCh}$, water with a temperature of $26.2^{\circ} \mathrm{C}$ is cooled to $19.1{ }^{\circ} \mathrm{C}$ due to chilled water, which is heated from $7^{\circ} \mathrm{C}$ to $12^{\circ} \mathrm{C}$. After that, water with a flow rate of $400 \mathrm{~m} 3 / \mathrm{h}$ and a temperature of $19.1^{\circ} \mathrm{C}$ is returned to the intermediate circuit for the utilization of NPU reaction heat.

Thus, we obtain $27.4 \mathrm{MW}$ as useful heat energy during the utilization of NPU reaction heat, and 3.3 MW as a cold in AbCh. Two AbCh-2000Vn produced by Teplosibmash OJSC with a total cooling capacity of $3600 \mathrm{~kW}$ can be considered for installation based on the calculation results. 
a)

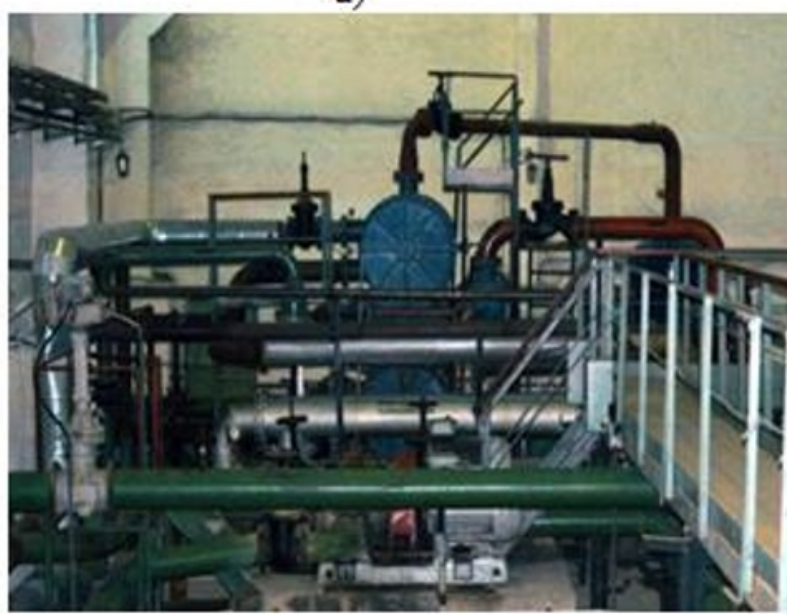

b)

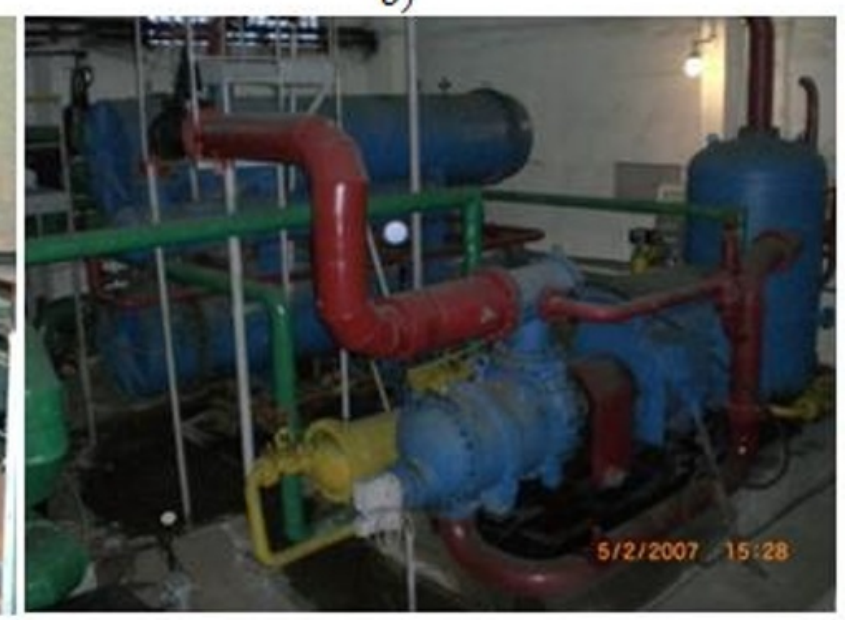

Fig. 5. The first industrial NT-3000 heat pump at Kazzinc JSC in the Republic of Kazakhstan.

A cooling water circuit with cooling parameters from $33{ }^{\circ} \mathrm{C}$ to $25^{\circ} \mathrm{C}$ is also required for $\mathrm{AbCh}$,. As a cooling circuit, the plant's water recycling system or its own local small-sized cooling tower can be used.

\section{$5 \mathrm{HT}$ use in the zink production}

Currently, the use of HT in Russia and the CIS countries is just beginning to become popular. So in the Republic of Kazakhstan, an example of the use of HPU is the NT3000 heat pump with a capacity of 3 MW at Kazzinc JSC (Ust-Kamenogorsk). HPU is intended for heating feed water before chemical water purification from + $8^{\circ} \mathrm{C}$ to $+40^{\circ} \mathrm{C}$ and at the same time for "cooling" circulating water, which is then used during electrolysis. The circulating water cooling allows to replace the purchased artesian water, thereby reducing material production costs. Table 2 shows the results of the heat pump NT - 3000 adoption [8].

Figures 5a and 5b show how NT-3000 looks like.

Table 2. The results of the heat pump NT -3000 adoption.

\begin{tabular}{|c|l|c|}
\hline Num. & \multicolumn{1}{|c|}{ Indicator } & Value \\
\hline $\mathbf{1}$ & Coefficient of performance & 6.8 \\
\hline $\mathbf{2}$ & Recycled water cooling & $7.7^{\circ} \mathrm{C}$ \\
\hline $\mathbf{3}$ & Cost of thermal energy at HPU & 198 tenge / Gcal \\
\hline $\mathbf{4}$ & Cost of cold & 440 tenge / Gcal \\
\hline $\mathbf{5}$ & Capital Costs, including: & $\begin{array}{c}27.63 \text { million } \\
\text { tenge }\end{array}$ \\
\hline $\mathbf{6}$ & Cost of HPU & $\begin{array}{c}24.9 \text { million } \\
\text { tenge }\end{array}$ \\
\hline $\mathbf{7}$ & $\begin{array}{l}\text { Total heat and cold production } \\
\text { for 1999-2004 in cash }\end{array}$ & $\begin{array}{c}57.2 \text { million } \\
\text { tenge }\end{array}$ \\
\hline $\mathbf{8}$ & $\begin{array}{l}\text { Cost of electricity to drive the } \\
\text { compressor }\end{array}$ & $\begin{array}{c}4.55 \text { million } \\
\text { tenge }\end{array}$ \\
\hline $\mathbf{9}$ & $\begin{array}{l}\text { Estimated simple payback } \\
\text { period }\end{array}$ & About 2 years \\
\hline
\end{tabular}

Later, in order to utilize the circulating water lowgrade heat of the whole enterprise of Kazzinc JSC, a design of a $30 \mathrm{MW}$ heat pump station was agreed. With the help of this project, it becomes possible to completely utilize the heat of circulating water (29.8 MW) and use this heat in the winter period for the needs of heating, ventilation and hot water supply, which will make it possible to refuse the services of a third-party power plant [10].

\section{Prospects for the use of TT at the Aksu Ferroalloy Plant - a branch of Kazchrome JSC}

In the Republic of Kazakhstan in 2018-2020, scientists of the Research Institute "Energy Saving and Energy Efficient Technologies" ("ES\&EET") of ENU named after L.N. Gumilyov and the Start Company BMTU LLC (Astana) conduct joint research to evaluate the possibilities of using HPU at the Aksu Ferroalloy Plant (AFP) - a branch of Kazchrome TNC JSC using alternative energy sources at various enterprise facilities [15].

The prospects for the use of HPU in the smelting shop No. 4 thermal circuit using the water recycling system (WRS) low-grade heat with temperatures up to $+35^{\circ} \mathrm{C}$ directed to the HPU evaporators were studied.

HPU recovers the WRS waste heat of the AFP (from $4,000 \mathrm{~m} 3 / \mathrm{h}$ to $6,000 \mathrm{~m} 3 / \mathrm{h}$ ), which is used for cooling in the enterprise cooling towers. Thus, all utilized heat can be sent to heat the various facilities of the workshop. During the implementation of this project, it is planned to cover the total heat load (2.01 MW = heating + hot water supply) of enterprise workshop No. 4.

In accordance with the initial data, presented by AFP specialists, an enlarged calculation of the HPU efficiency use for heat supply of objects in the workshop No. 4 (Table 3) is carried out. From which it follows that the annual economic effect from the use of HPU in the workshop amounts to 42.812 million tenge, the payback period of the proposed project is 3.53 years [15]. 
a)

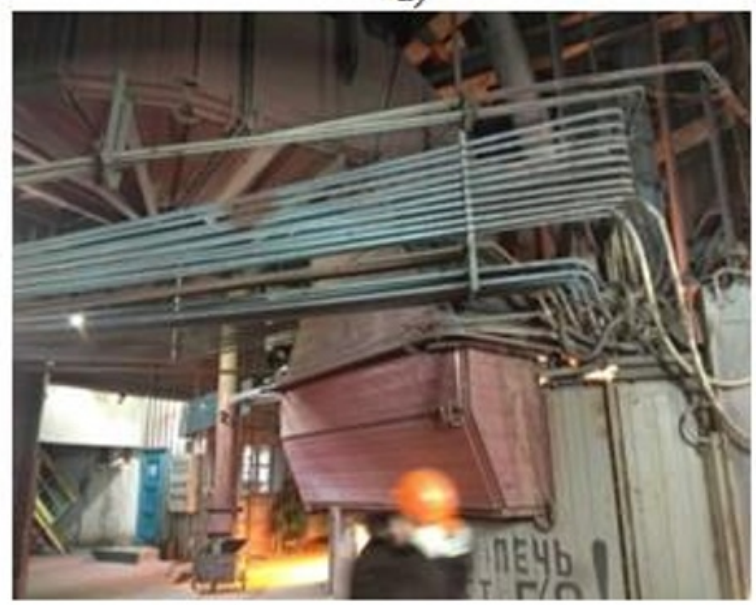

b)

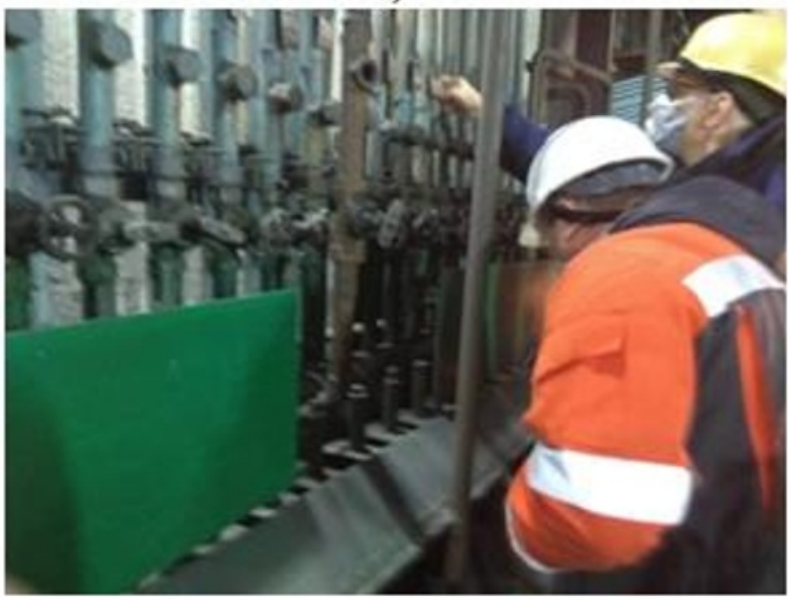

Fig. 6. Production site of the melting shop No. 4 of the AFP, where heat pumps installation with 2.34 MW total capacity of is planned.

Table 3. Comparison of annual operating thermal energy generation costs of the AFP smelting shop №4 from various heat sources.

\begin{tabular}{|l|c|c|}
\hline \multicolumn{1}{|c|}{ Heat source } & $\begin{array}{c}\text { Annual } \\
\text { operating } \\
\text { costs, million } \\
\text { tenge* }\end{array}$ & $\begin{array}{c}\text { Cost 1 Gcal/hour } \\
\text { Tenge/Gcal } \\
\text { (including VAT) }\end{array}$ \\
\hline $\begin{array}{l}\text { Heat supply of } \\
\text { workshop №4 from the } \\
\text { district heating plant } \\
\text { (ROK-2) of the AFP }\end{array}$ & 50.928 & 2500 \\
\hline Heat pump boiler room & 8.116 & 490 \\
\hline $\begin{array}{l}\text { The data are for the period summer 2019, the exchange rate is - } 1 \$= \\
\text { 381 tenge }\end{array}$ \\
\hline
\end{tabular}

\section{Conclusion}

The article provides examples of the HT use in industrial enterprises.

Utilization of NPU low-grade heat in HPU with a heat capacity of $7.2 \mathrm{MW}$ allows to get up to $30 \mathrm{MW}$ of usable heat energy for heating the water of the heating network and makeup water in winter.

The presented scheme for the low-grade heat utilization using $\mathrm{AbCh}$ in the summer period allows to obtain 27.4 MW as useful heat energy. The source of thermal energy for the $\mathrm{AbCh}$ is the water of the NPU intermediate circuit with a temperature of $85^{\circ} \mathrm{C}$ and a flow rate of up to $400 \mathrm{~m} 3 / \mathrm{h}$. Calculations show that the $\mathrm{AbCh}$ is able to produce cold in an amount of $3.3 \mathrm{MW}$ with cooling parameters for chilled water from $12^{\circ} \mathrm{C}$ to $7^{\circ} \mathrm{C}$.

The HPU at Kazzinc JSC allows not only to meet the needs of the enterprise in thermal energy, but also allows to reduce material costs for the purchase of artesian water. A larger project of the $30 \mathrm{MW}$ station allows to completely decline the services of a third-party power plant.

The utilization of waste heat from the recycling water supply system of the AFP smelting shop No. 4 in HPU makes it possible to:
- decline the traditional source of heat - the coal boiler ROK-2 with significant operating costs;

- significant decrease greenhouse gas emissions;

- ensure year-round reliable heat supply;

- reduce the capacity of circulation pumps and reduce water consumption for production needs.

Similar events can be carried out at almost any large metallurgical enterprises in the industrial regions of Russia and Kazakhstan.

\section{References}

[1] I. Sultanguzin, Environmental safety and energy efficiency of industrial heat power systems: a training manual (Moscow: Publishing House MPEI, 288, 2013)

[2] L. Zhiqiang, X. Nan, Y. Sheng, Thermodynamic and parametric analysis of a coupled $\mathrm{LiBr} / \mathrm{H} 2 \mathrm{O}$ absorption chiller / Kalina cycle for cascade utilization of low-grade waste heat, Energy Conversion and Management 205, 112370 (2020)

[3] M.L. Chougui, S. Zid, Energy analysis of single effect absorption chiller ( $\mathrm{LiBr} / \mathrm{H} 2 \mathrm{O}$ ) in an industrial manufacturing of detergent, Energy Procedia 50, 105-112 (2014)

[4] S. Prishchepova, I. Sultanguzin, The use of absorption chillers for house cooling in the summer using the solar collectors excess heat, Proceedings of the eighth International SchoolSeminar for Young Scientists and Specialists "Energy saving - theory and practice" (Moscow: Publishing House MPEI, 411-414, 2016)

[5] C. Peizhe, Y. Mengxiao, L. Zhiqiang, Zh. Zhaoyou, Y. Sheng, Energy, exergy, and economic (3E) analyses and multi-objective optimization of a cascade absorption refrigeration system for low-grade waste heat recovery, Energy Conversion and Management 184, 249-261 (2019)

[6] Y. Sheng, Q. Yu, W. Yifan, Y. Siyu, A novel cascade absorption heat transformer process using 
low grade waste heat and its application to coal to synthetic natural gas, Applied Energy 202, 42-52 (2017)

[7] E. Khosrow, F.J. Gerard, S.F. Amy, Thermoeconomic analysis of steady state waste heat recovery in data centers using absorption refrigeration, Applied Energy 139, 384-397 (2015)

[8] A. Alimgazin, Development of schemes and technologies for the use of non-traditional and renewable energy sources for heat supply of isolated objects (author. doc tech. sciences. Almaty: AUPET, 44, 2010)

[9] S. Prishchepova, I. Sultanguzin, Example of energy efficiency improving of the enterprise using $\mathrm{AbCh}$ in mining and metallurgical industry, Radioelectronics, electrical and power engineering, Moscow: Publishing House MPEI 2 , 356 (2016)

[10] A. Alimgazin, S. Alimgazina, A. Bakhtiyarov, Analysis of the prospects for the use of heat pump technologies at metallurgical enterprises of the Republic of Kazakhstan, Proceedings of the VIII International Scientific and Practical Conference Energy-efficient and resource-saving technologies in industry. 100 years of national metallurgical furnaces design, 238-250 (2016)

[11] I. Sultanguzin, T. Shomova, P. Shomov, V. Dostovalov, The use of heat pumps in gas processing plants. Abstracts and reports of the XV Minsk International Forum on Heat and Mass Transfer 3, 420-424 (2016)

[12] D. Keppler, Absorption chillers as a contribution to a climate-friendly refrigeration supply regime: Factors of influence on their further diffusion, Journal of Cleaner Production 172, 1535-1544 (2018)

[13] A. Fedyukhin, I. Sultanguzin, S. Kurzanov, R. Belov, A. Bakulin, T. Shomova, The use of applied software to solve the problems of industrial heat power: a training manual (Moscow: MEI Publishing House, 88, 2016)

[14] THERMOFLEX. Fully Flexible Heat Balance Engineering Software, THERMOFLEX User's Manual, Thermoflow, Inc. 3, 1139 (2013)

[15] A. Alimgazin, S. Alimgazina, Prospects for the use of energy-saving heat pump technologies using alternative energy sources at the Aksu Ferroalloy Plant, a branch of Kazchrome TNK JSC, Bulletin of PSU named S. Toraigyrova, Series Power engineering 4, 35-38 (2019) 